\title{
Macrophage migration inhibition factor is elevated in pregnancy, but not to a greater extent in preeclampsia
}

Received: 16 November 2005/ Accepted: 20 November 2005/Published online: 21 December 2005

(C) Springer-Verlag 2005

\begin{abstract}
Background: Maternal serum concentrations of macrophage migration inhibitory factor (MIF) have recently been reported to be elevated in cases with preeclampsia. These findings may be important in increasing our understanding of the underlying events leading to the development of preeclampsia, as this cytokine is also expressed in the placenta, where it has been shown to possess immunemodulatory activities. For this reason we attempted to independently verify this report. Methods: Plasma levels of MIF were assessed by ELISA in plasma samples collected from normal healthy male and female blood donors ( $n=20$ per group), as well as healthy normal pregnant women in all three trimesters of pregnancy $(n=60)$. In addition, MIF levels were examined from cases with mild and severe preeclampsia $(n=20$ per study cohort) and matched normotensive pregnancies $(n=20)$. Results: MIF levels were found to be elevated in pregnancy (median $=10.1 \mathrm{ng} / \mathrm{ml}$ ) when compared to non-pregnant controls (median $=1.7 \mathrm{ng} /$ $\mathrm{ml}$ ). A moderate, but not significant, elevation was found to occur from the first to the third trimester of pregnancy. No significant difference was found to occur between the two preeclampsia study groups when compared to the normotensive control group. Conclusions: Our data suggest that circulatory MIF concentrations are elevated throughout pregnancy, but are not further increased in preeclampsia.
\end{abstract}

Keywords MIF $\cdot$ Immunemodulation · Pregnancy $\cdot$ Preeclampsia

S. Hristoskova $\cdot$ W. Holzgreve $\cdot$ X. Y. Zhong $\cdot$ S. Hahn $(\bowtie)$ Laboratory for Prenatal Medicine, University Women's Hospital/ Department of Research, University Hospital Basel, Spitalstrasse 21, 4031 Basel, Switzerland

E-mail: shahn@uhbs.ch

Tel.: + 41-61-2659224

Fax: + 41-61-2659399

\section{Introduction}

Migration inhibitory factor (MIF) was one of the earliest cytokines to be described as a T-cell soluble factor which inhibited random macrophage migration [1]. Human MIF consists of a peptide of 114 amino acids which form a homotrimer. In the interim, MIF expression has been found in several other cell types, including macrophages, neutrophils, anterior pituitary cells and bronchial alveolar cells $[2,3]$.

The presence of MIF in the anterior chamber of the eye has drawn particular interest [2], as in this instance MIF was shown to possess distinct immunosuppressive activities. This study showed that MIF hindered the chemotaxis of neutrophils and macrophages, suppressed $\mathrm{T}$ - and B-cell proliferation in vitro, and also prevented the activation and lytic activity of NK cells. In this manner, the presence of MIF in the eye assisted with the establishment of a condition of immune privilege in this vital tissue. In this context it has also been shown that MIF may promote malignant cell transformation by inhibiting tumour-specific immune responses and by enhancing neovascularisation [3].

In this regard it is worth noting that pregnancy involves an intricate balance of the maternal immune system with the presence of a semi-allogeneic foreign fetus, and has also been suggested to involve a state of immune privilege, in that undesired inflammatory responses are actively suppressed in the placenta. Hence, previous reports describing MIF activity in placental extracts [4], its expression in chrorionic villi $[5,6]$ and more recently by amniotic epithelial cells [7], may serve to indicate that placental MIF expression may be important for the maintenance of normal pregnancy.

In this context a recent report has indicated that circulatory MIF concentrations are elevated under conditions of preeclampsia [8]. As preeclampsia is associated with an altered response of the maternal immune system [9], it is possible that aberrant expression of MIF may play a role in the development of this imbal- 
ance. For this reason we have sought to independently verify that MIF concentrations are elevated in preeclampsia.

\section{Materials and methods}

\section{Samples from normal pregnancies}

This study was approved by the Institutional Review Board of the Canton of Basel, and written informed consent was requested in all instances. For the recruitment of maternal plasma samples from normal pregnancies, 60 samples were collected from normal healthy pregnant women in the first to third trimester (range $=11+3$ to $38+1$ weeks). Twenty samples were also obtained from normal healthy female and male blood donors (Swiss Red Cross, Basel, Switzerland).

\section{Preeclampsia samples}

For the analysis of cases with preeclampsia, we used a study cohort which has previously been described [10, 11]. In the current study we used a subset of the initial cohort, in which the preeclampsia study group now consisted of 20 cases with the mild form and 20 cases with the severe form of the disorder and 20 gestational age-matched normotensive controls samples. Preeclampsia was determined by a blood pressure of $\geq 140$ / $90 \mathrm{mmHg}$ in two determinations $4 \mathrm{~h}$ apart or by a diastolic blood pressure of $\geq 110 \mathrm{mmHg}$ and an associated proteinuria of $\geq 300 \mathrm{mg} / 24 \mathrm{~h}$ after 20 weeks' gestation. Patients with severe preeclampsia also met at least one of the following criteria: blood pressure $>160 / 110 \mathrm{mmHg}$ on at least two occasions, proteinuria of $>5 \mathrm{~g}$ in 24-h urine collection, eclampsia, HELLP (hemolysis, elevated liver enzymes and low platelet count) syndrome (total bilirubin concentration $>1.2$ or lactate dehydrogenase activity $>600 \mathrm{IU} / 1$; aspartate aminotransferase $>70 \mathrm{IU} / 1 ;<100,000$ platelets/dl), unremitting headache, right upper-quadrant pain or ultrauterine growth at $<5$ th percentile.

\section{MIF ELISA}

The concentrations of MIF in serum samples were measured by a colorometric sandwich ELISA. ELISA plates were coated with $100 \mu \mathrm{l} /$ well of antihuman MIF monoclonal antibody $(2.0 \mu \mathrm{g} / \mathrm{ml})(\mathrm{R} \& \mathrm{D}$ Systems) and incubated overnight at room temperature. The plates were washed three times with washing solution $(10 \mathrm{mM}$ PBS, pH 7.4, 0.05\% Tween 20), blocked by adding $300 \mu \mathrm{l}$ of blocking solution (10 mM PBS, pH 7.4, 2\% bovine serum albumin) and incubated at room temperature for $1.5 \mathrm{~h}$. After washing three times, the samples diluted 1:1 in Tris-buffered saline-BSA $(20 \mathrm{mM}$ Tris$\mathrm{HCl}, 150 \mathrm{mM} \mathrm{NaCl}, 1 \% \mathrm{BSA}, 0.05 \%$ Tween) were added in triplicate $(100 \mu \mathrm{l} /$ well $)$ and incubated for $2 \mathrm{~h}$ at room temperature. The plates were then washed three times and $100 \mu \mathrm{l}$ of biotinylated goat antihuman MIF polyclonal antibody (200 $\mathrm{ng} / \mathrm{ml})$ (R\&D Systems) was added to each well and incubated for $2 \mathrm{~h}$ at room temperature. The plates were washed again and strepatavidin horseradish peroxidase (Zymed, San Francisco, CA, USA) was added to each well and incubated for $20 \mathrm{~min}$ at room temperature. The plates were washed and 3,3', 5,5'-tetramethylbenzidine (Zymed) was added. After $20 \mathrm{~min}$, the reaction was stopped by adding $\mathrm{H}_{2} \mathrm{SO}_{4}$. The absorbance was measured at $450 \mathrm{~nm}$ using an ELISA microplate reader. MIF concentrations were expressed as nanogram per millimeter. The mean coefficient of variation of the assay was $4.7 \%$.

\section{Statistics}

The data were analysed with the Mann-Whitney rank sum test using the SigmaStat (SPSS ${ }^{\circledR}$ Inc, Chicago,IL,USA) software package. Data are presented by box plots (Fig. 1), indicating the median value (line in the box), the 75th and 25th percentiles (limits of box) and the 10th and 90th percentiles (upper and lower horizontal bars), respectively.

\section{Results}

Our analysis indicated that the circulatory concentrations of MIF were elevated in normal pregnancy (median $=10.1 \mathrm{ng} / \mathrm{ml}$ ) when compared to samples obtained from normal non-pregnant female blood donors (median $=1.7 \mathrm{ng} / \mathrm{ml}$ ). Although the levels of circulatory MIF were slightly higher in samples obtained from healthy male blood donors $(2.8 \mathrm{ng} / \mathrm{ml})$, these were not significantly different from those of female blood donors. Our analysis indicated that a moderate, but not significant,

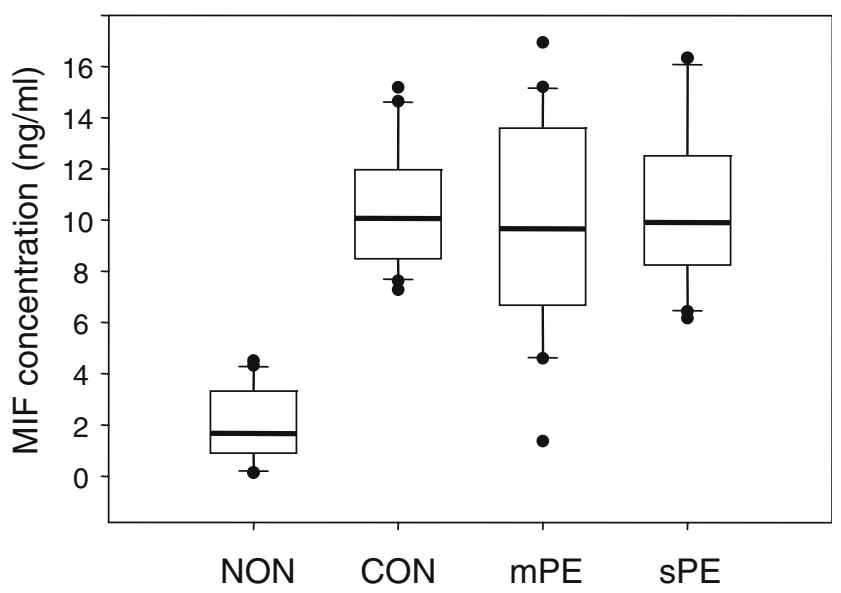

Fig. 1 Box plot illustrating circulatory MIF concentrations in nonpregnant healthy female blood donors $(N O N)$, normotensive control cases $(C O N)$, cases with mild preeclampsia $(m P E)$ or severe preeclampsia $(s P E)$ 
Table 1 Concentrations of MIF in normal non-pregnant donors and throughout pregnancy

Values are given as median and range in brackets

Table 2 MIF concentrations and clinical characteristics of the preeclampsia study groups and matched normotensive control cohort

Values are given as median and range in brackets

\begin{tabular}{llllll}
\hline & $\begin{array}{l}\text { Healthy female } \\
\text { blood donors }\end{array}$ & $\begin{array}{l}\text { Healthy male } \\
\text { blood donors }\end{array}$ & $\begin{array}{l}\text { First trimester } \\
\text { of pregnancy }\end{array}$ & $\begin{array}{l}\text { Second trimester } \\
\text { of pregnancy }\end{array}$ & $\begin{array}{l}\text { Third trimester } \\
\text { of pregnancy }\end{array}$ \\
\hline$n$ & 20 & 20 & 8 & 32 & 20 \\
$\begin{array}{l}\text { Gestational age } \\
\begin{array}{l}\text { MIF concentration } \\
(\mathrm{ng} / \mathrm{ml})\end{array}\end{array}$ & $\mathrm{N} / \mathrm{A}$ & $\mathrm{N} / \mathrm{A}$ & $11+6$ & $16+0$ & $31+5$ \\
\hline
\end{tabular}

\begin{tabular}{llll}
\hline & $\begin{array}{l}\text { Normotensive } \\
\text { controls }\end{array}$ & $\begin{array}{l}\text { Mild } \\
\text { preeclampsia }\end{array}$ & $\begin{array}{l}\text { Severe } \\
\text { preeclampsia }\end{array}$ \\
\hline$n$ & 20 & 20 & 20 \\
Systolic blood pressure & $127(110-134)$ & $161(150-191)$ & $193(160-239)$ \\
Diastolic blood pressure & $75(67-87)$ & $102(96-108)$ & $120(110-140)$ \\
Fetal weight at birth $(\mathrm{g})$ & $3,264(2024-3940)$ & $2,645(1151-3455)$ & $1,964,(1144-3135)$ \\
MIF concentration $(\mathrm{ng} / \mathrm{ml})$ & $10.1(7.3-15.3)$ & $9.7(1.4-16.9)$ & $9.9(6.2-16.3)$ \\
\hline
\end{tabular}

increase in the concentration of circulatory MIF occurred from the first to the third trimester of pregnancy (Table 1).

As circulatory MIF concentrations have recently been reported to be elevated in cases with preeclampsia, we next examined this aspect. For our analysis, we used samples obtained from 20 cases with a mild form of this disorder, as well as a further 20 samples from cases with a severe form of this disorder. The latter group included cases with HELLP syndrome and eclampsia. Our analysis indicated that circulatory MIF concentrations were not significantly different in the cases with mild or severe preeclampsia when compared to the matched normotensive control group (Table 2, Fig. 1).

\section{Discussion}

Elevated concentrations of MIF have recently been reported to occur in pregnancies with manifest preeclampsia [8]. These data are in contrast to those we have observed in our current analysis, where we observed no discernible elevation in MIF levels in cases with preeclampsia when compared to matched normotensive controls. While we observed similar MIF concentrations in our cases with preeclampsia when compared to those observed by Todros et al. [8] (9.7 ng/ $\mathrm{ml}$ in mild preeclampsia and $9.9 \mathrm{ng} / \mathrm{ml}$ in severe preeclampsia vs. $12.74 \mathrm{ng} / \mathrm{ml}$ ), the same was not true for samples from normal healthy pregnancies. In these cases we consistently observed MIF concentrations of around $10 \mathrm{ng} / \mathrm{ml}$ in all 80 samples from normal pregnancies, which are considerably higher than those observed by Todros et al. [8] in their control cohort (median $=5.3 \mathrm{ng} /$ $\mathrm{ml}$ ). Although it is possible that this disparity may be attributable to the difference in sample sizes between the two studies, our data is obtained from a very large cohort $(n=80$ samples from normal pregnancies and $n=40$ samples from pregnancies with manifest preeclampsia). Consequently, our data do suggest that circulatory MIF concentrations are elevated in pregnancy, when compared to non-pregnant controls, but are not further elevated under conditions of preeclampsia.

These findings may be noteworthy as the elevated presence of MIF throughout pregnancy implies that its continued presence is important. As MIF possesses pleotropic activities, it is possible that these may include its ability to promote neovascularisation, which is certainly of importance for efficient placentation $[3,6]$.

However, it is also probable that in pregnancy, MIF may function in its immunemodulatory capacity by promoting a condition of immune privilege, especially in its ability to inhibit the cytolytic activity of CD8 T cells and NK cells [2]. In this manner it can be postulated that the elevated presence of MIF in pregnancy may prevent the destruction of semi-allogeneic placental tissue by inadvertently activated maternal immune effector cells. Furthermore, as there is little evidence of the increased activity of maternal NK or CD8 T cells in preeclampsia [9], this may help to explain our observation that MIF levels are not altered in this disorder, in that there is no increased requirement for MIF activity in preeclampsia.

As such our data provide evidence for the involvement of another factor in the complex regulatory mechanisms maintaining the balance between the maternal and fetal immune systems to ensure a beneficial pregnancy outcome. However, since we also detected MIF expression in the ovary (data not shown), another immune privileged site [3, 12], it is likely that MIF may play a general role in the maintenance of this immunological phenomenon, apart from its apparent role in pregnancy [6].

Acknowledgements This study was supported by funds from the University Women's Hospital/Department of Research, Basel, Switzerland. We thank Drs. D. Huang, C. Rusterholz and A.K. Gupta for their helpful comments. 


\section{References}

1. Bloom BR, Bennett B (1966) Mechanism of a reaction in vitro associated with delayed-type hypersensitivity. Science 153(731): $80-82$

2. Apte RS, Sinha D, Mayhew E, Wistow GJ, Niederkorn JY (1998) Cutting edge: role of macrophage migration inhibitory factor in inhibiting NK cell activity and preserving immune privilege. J Immunol 160(12):5693-5696

3. Mitchell RA (2004) Mechanisms and effectors of MIF-dependent promotion of tumourigenesis. Cell Signal 16(1):13-19

4. Zeng FY, Weiser WY, Kratzin H, Stahl B, Karas M, Gabius HJ (1993) The major binding protein of the interferon antagonist sarcolectin in human placenta is a macrophage migration inhibitory factor. Arch Biochem Biophys 303(1):74-80

5. Arcuri F, Cintorino M, Vatti R, Carducci A, Liberatori S, Paulesu L (1999) Expression of macrophage migration inhibitory factor transcript and protein by first-trimester human trophoblasts. Biol Reprod 60(6):1299-1303

6. Akoum A, Metz CN, Morin M (2005) Marked increase in macrophage migration inhibitory factor synthesis and secretion in human endometrial cells in response to human chorionic gonadotropin hormone. J Clin Endocrinol Metab 90(5):29042910
7. Li H, Niederkorn JY, Neelam S, Mayhew E, Word RA, McCulley JP, Alizadeh H (2005) Immunosuppressive factors secreted by human amniotic epithelial cells. Invest Ophthalmol Vis Sci 46(3):900-907

8. Todros T, Bontempo S, Piccoli E, Ietta F, Romagnoli R, Biolcati M, Castellucci M, Paulesu L (2005) Increased levels of macrophage migration inhibitory factor (MIF) in preeclampsia. Eur J Obstet Gynecol Reprod Biol

9. Sacks GP, Studena K, Sargent K, Redman CW (1998) Normal pregnancy and preeclampsia both produce inflammatory changes in peripheral blood leukocytes akin to those of sepsis. Am J Obstet Gynecol 179(1):80-86

10. Zhong XY, Laivuori H, Livingston JC, Ylikorkala O, Sibai BM, Holzgreve W, Hahn S (2001) Elevation of both maternal and fetal extracellular circulating deoxyribonucleic acid concentrations in the plasma of pregnant women with preeclampsia. Am J Obstet Gynecol 184(3):414-419

11. Hristoskova S, Holzgreve W, Hahn S (2004) Anti-phospholipid and anti-DNA antibodies are not associated with the elevated release of circulatory fetal DNA in pregnancies affected by preeclampsia. Hypertens Pregnancy 23(3):257-268

12. Streilein JW (1990) Anterior chamber associated immune deviation: the privilege of immunity in the eye. Surv Ophthalmol 35(1):67-73 